\title{
Aspects Regarding the Behaviour of Co-Cr-W Alloys Produced by Selective Laser Melting (SLM) to Electrochemical Corrosion
}

\author{
ALICE MURARIU ${ }^{1}$, ELENA-RALUCA BACIU ${ }^{1 *}$, NICOLETA IOANID ${ }^{1 *}$, \\ CATALINA HOLBAN CIOLOCA ${ }^{1}$, LAURA ELISABETA CHECHERITA ${ }^{1}$, \\ VERONICA TOBA ${ }^{2}$, OVIDIU STAMATIN ${ }^{1}$, ROXANA-IONELA VASLUIANU ${ }^{1}$ \\ ${ }^{1}$ Grigore T. Popa University of Medicine and Pharmacy, Faculty of Dental Medicine, 16 Universitatii Str., 700115, Iasi, \\ Romania \\ ${ }^{2}$ Dunarea de Jos University of Medicine and Pharmacy, 47 Domneasca Str., 800008, Galati, Romania
}

\begin{abstract}
The goal of this study is to investigate the behaviour of Co-Cr-W dental alloys obtained by additive manufacturing/SLM to electrochemical corrosion in Fusayama-Meyer artificial saliva solution. The specimens processed by different techniques were analysed from the structural and chemical view point by using a scanning electron microscope fitted with an EDS electron detector. The different sand blasting of the surface of metal materials will determine their different behaviour in the electrolyte solution.
\end{abstract}

Keywords: dental Co-Cr-W alloys, Selective Laser Melting, electrochemical corrosion

\section{Introducere}

The use of alloys in dental medicine requests the development of new concepts for technological processing so that they may ensure the obtaining of some long term biocompatible prosthetic restorations.

The traditional casting methods were used for many years to obtain prosthetic restorations from Co-Cr-W based alloys [1-3].

The new CAD/CAM concept within SLM technology [4-6] aims to use the 3D technology in order to design the prosthetic piece, the making of the finished part file and the processing of the part on specialized equipment. The two CAD and CAM components have been designed on different principles, the CAD component relying on the obtaining of information while the CAM technique represents the processing by melting of the powder particles forming the alloy and the obtaining of the finished part. As compared to the traditional casting techniques, SLM reduces operator's error probability and minimizes the casting flaws while providing higher manufacturing precision [7-9]. SLM products have a higher density a low corrosion coefficient thus improving the surface status of the alloy [10-12].

The corrosion process is tightly related to the composition and physico-chemical processing of the alloy which may change the surface status of the future metal skeleton under the action of environmental factors. The elements of the prosthetic field may be influenced by the application of the different components of the prosthesis of or certain substances, determined by different techniques [13-15].

The alveolar bone resorbtion is significantly correlated with the clinical pathology of the patient and is induced by the modification of the forces direction on the level of odontal support [16-19].

\section{Materials and methods}

The goal of these experimental researches is the analysis of Co-Cr-Wdental alloys obtained by additive manufacturing/SLM, to electrochemical corrosion in Fusayama-Meyer artificial saliva solution. 
We analysed experimental specimens from $\mathrm{Co}-\mathrm{Cr}-\mathrm{W}$ alloys obtained by additive manufacturing/3D printing having the size of powder layers of $25 \mu \mathrm{m}$, the power of the laser beam of $80.3 \mathrm{~W}$, the scanning speed of $500 \mathrm{~mm} / \mathrm{s}$ and the exposure time of $40 \mu \mathrm{s}$.

The surface of the specimens obtained by SLM was processed in different ways: non-sand blasted (NS), sand blasted once(1S) and sand blasted in two successive phases (2S).

The electrochemical corrosion tests were conducted in Fusayama-Meyer artificial saliva solution having $p \mathrm{H}=5.3$, and a chemical composition very close to natural saliva (table 1 ).

Table 1. Chemical composition of fusayama-meyer artificial saliva used for electrochemical corrosion tests

\begin{tabular}{ccccccccc}
\hline \multirow{2}{*}{ Artificial saliva } & $\begin{array}{c}\mathrm{NaCl} \\
\mathrm{g} / \mathrm{L}\end{array}$ & $\begin{array}{c}\mathrm{KCl} \\
\mathrm{g} / \mathrm{L}\end{array}$ & $\begin{array}{c}\mathrm{NaHCO}_{3} \\
\mathrm{~g} / \mathrm{L}\end{array}$ & $\begin{array}{c}\mathrm{Urea} \\
\mathrm{g} / \mathrm{L}\end{array}$ & $\begin{array}{c}\mathrm{CaCl}_{2} \\
\mathrm{~g} / \mathrm{L}\end{array}$ & $\begin{array}{c}\mathrm{NaH}_{2} \mathrm{PO}_{4} \cdot \mathrm{H}_{2} \mathrm{O} \\
\mathrm{g} / \mathrm{L}\end{array}$ & $\begin{array}{c}\mathrm{Na}_{2} \mathrm{~S} \\
\mathrm{~g} / \mathrm{L}\end{array}$ \\
$\begin{array}{c}\text { Fusayama- } \\
\text { Meyer }\end{array}$ & 0.4 & 0.4 & 0.69 & 1 & 0.65 & 0.69 & 0.05 \\
\hline
\end{tabular}

Specimens were analysed structurally and chemically by using a scanning electron microscope fitted with an EDS electron detector.

\section{Results and discussions}

Figure 1 presents the SEM images of the surfaces of experimental specimens for 500:1 image amplification power a), c) and e).

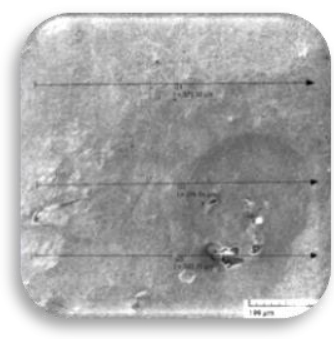

a.

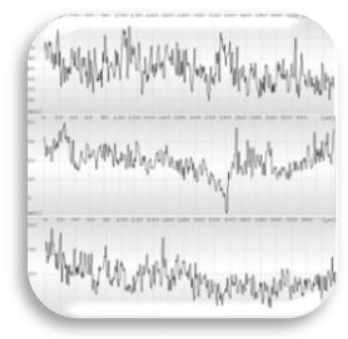

b.

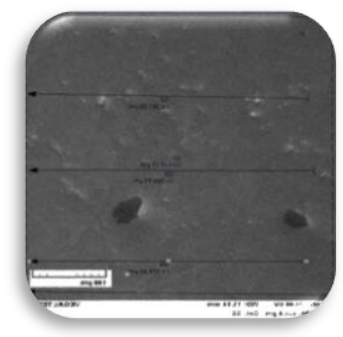

e.

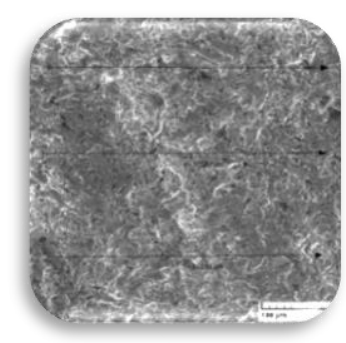

c.

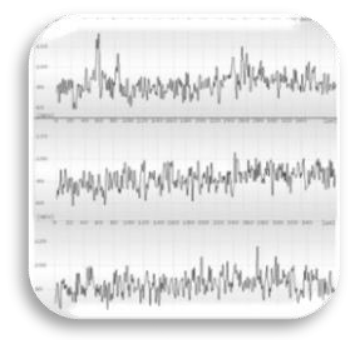

f.

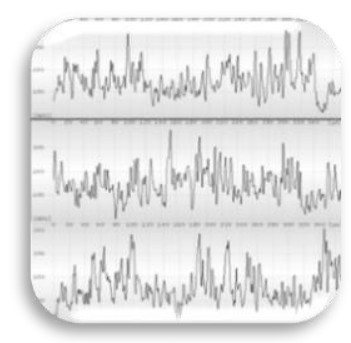

d.

Figure 1. SEM images of the surfaces of experimental specimens after the electrochemical corrosion test: a) NS specimen at500:1 power b) rugosity of NS specimen, c) 1Sspecimen at500:1 power, d) rugosity of $1 \mathrm{~S}$ specimen surface,e) $2 \mathrm{~S}$ specimen at 500:1 power,

f) rugosity of $2 \mathrm{~S}$ specimen surface

The appearance of corrosion is generalized in all three cases accompanied by the formation of reaction compounds on the material surface.

Following the different processing of the surface of metal materials we may notice their different behaviour in electrolyte solution.

The NS specimen has a flawed area highlighted by the supplementary corrosion of surface due to the superficial melting of the spherical particles of metal material while they remained intact following the $3 \mathrm{D}$ printing process, a fact which led to the additional corrosion of such area. 
On $1 \mathrm{~S}$ specimen we may notice several variations, a fact indicating the different behaviour of the areas on the same specimen from the view point of resistance to corrosion in electrolyte solution. In case of $2 \mathrm{~S}$ specimen, we may notice a lower rugosity of the surface by about 100 units as compared to the other two specimens.

Table 2 presents the chemical composition of the surface of NS specimen after the electrochemical corrosion tests and cleaning by ultrasonic treatment. The results are presented both in atomic and mass percentages, and the detector error is also mentioned.

Table 2. Chemical composition of the surface of ns specimen after the resistance test to electrochemical corrosion

\begin{tabular}{|c|c|c|c|c|c|c|}
\hline Element & AN & series & Net & [norm. wt.\%] & [norm. at.\%] & Error in \% \\
\hline Cobalt & 27 & K-series & 63266 & 48.21 & 37.57 & 1.22 \\
\hline Chrome & 24 & K-series & 45251 & 21.32 & 18.83 & 0.58 \\
\hline Tungsten & 74 & L-series & 6433 & 10.23 & 2.55 & 0.30 \\
\hline Oxygen & 8 & K-series & 4542 & 9.76 & 28.02 & 2.05 \\
\hline Sodium & 11 & K-series & 1473 & 4.06 & 8.12 & 0.34 \\
\hline Molybdenum & 42 & K-series & 248 & 4.00 & 1.91 & 0.31 \\
\hline Chlorine & 17 & K-series & 2414 & 1.24 & 1.60 & 0.25 \\
\hline Potassium & 19 & K-series & 2634 & 1.15 & 1.35 & 0.06 \\
\hline & & & Sum: & 100 & 100 & \\
\hline
\end{tabular}

The distribution of elements (Figure 2) shows the following aspects:

-cobalt and chrome oxidize evenly and in a generalized manner by forming a film of oxides resistant to the electrolyte used,

$-\mathrm{Cl}$ and $\mathrm{K}$ obviously form a couple on the surface of this auxiliary element having good stability even after the electrochemical corrosion test,

-Na participates in the formation of some compounds on the alloy surface, and the next phase in their definition is to form corrosion spots.

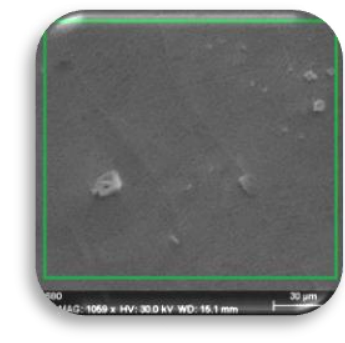

a.

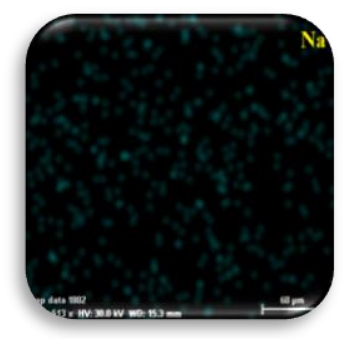

e.

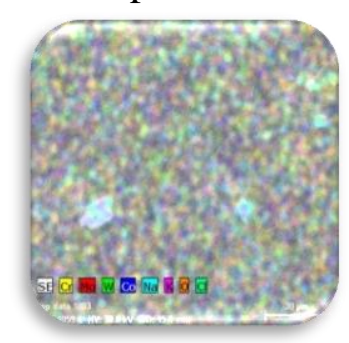

b.

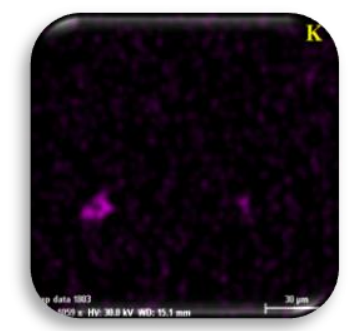

$\mathrm{f}$.

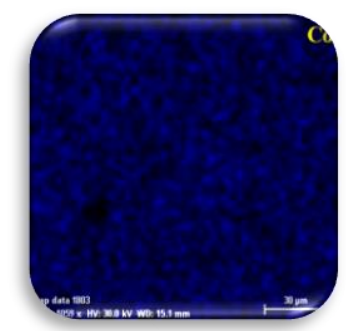

c.

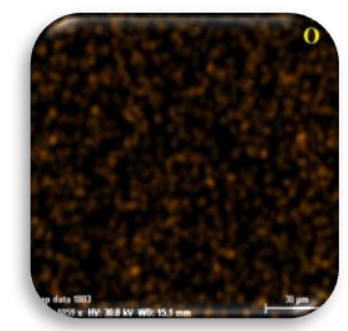

g.

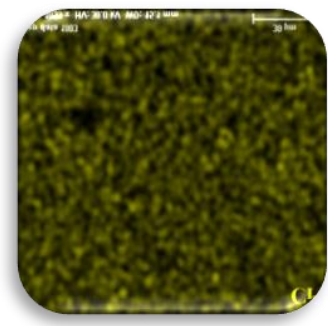

d.

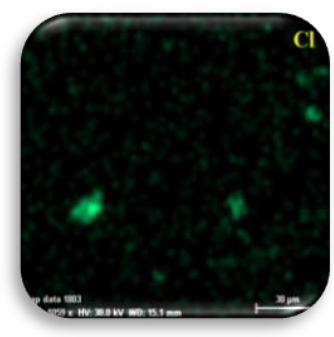

h.

Figure 2. Distribution of $\mathrm{Co}, \mathrm{Cr}, \mathrm{W}, \mathrm{Mo}, \mathrm{Na}, \mathrm{K}, \mathrm{Cl}$ and $\mathrm{O}$ elements: a) surface under analysis, b) distribution of all elements on the surface, c) Co, d) $\mathrm{Cr}$, e) $\mathrm{Na}, \mathrm{f}$ ) $\mathrm{K}, \mathrm{g}$ ) O, h) $\mathrm{Cl}$

Experimental specimens have the same chemical composition so that this study highlights aspects relating to the influence of surface preparation on the behaviour to electrochemical corrosion. 
From the distributions of elements identified on the surface of 1S specimen (table 3) we may notice corrosion by oxidization of the whole surface accompanied by the formation and maintaining of some potassium and sodium-based salts on the surface. The maintaining of these new compounds on the surface is due to the methods of surface preparation through the exposure of a larger material area. Their removal may be carried out by cleansing the surface with a solution that may eliminate these compounds by dissolution.

Table 3. Chemical composition of the surface of $1 \mathrm{~s}$ specimen after the test of resistance to electrochemical corrosion and cleaning by ultrasonic treatment

\begin{tabular}{c|c|c|c|c|c|c}
\hline Element & AN & series & Net & [norm. wt.\%] & [norm. at.\%] & Error in \% \\
\hline Cobalt & 27 & K-series & 69527 & 50.45 & 41.71 & 1.23 \\
\hline Chrome & 24 & K-series & 49995 & 21.23 & 20.47 & 0.67 \\
\hline Tungsten & 74 & L-series & 6073 & 9.35 & 2.39 & 0.39 \\
\hline Oxygen & 8 & K-series & 4609 & 9.35 & 27.72 & 1.77 \\
\hline Molybdenum & 42 & K-series & 309 & 4.85 & 2.42 & 0.30 \\
\hline Sodium & 11 & K-series & 813 & 2.32 & 4.64 & 0.21 \\
\hline Potassium & 19 & K-series & 1204 & 0.51 & 0.59 & 0.04 \\
\hline & & & Sum: & 100 & 100 & \\
\hline
\end{tabular}

Figure 3 presents the distribution of $\mathrm{Co}, \mathrm{Cr}, \mathrm{W}, \mathrm{Mo}, \mathrm{Na}, \mathrm{K}$ and $\mathrm{O}$ elements determined for $1 \mathrm{~S}$ specimen: a) surface under analysis, b) distribution of all elements on surface, c) Co, d) $\mathrm{Cr}, \mathrm{e}) \mathrm{W}, \mathrm{f}$ ) Mo, g) Na, h) K, i) O.

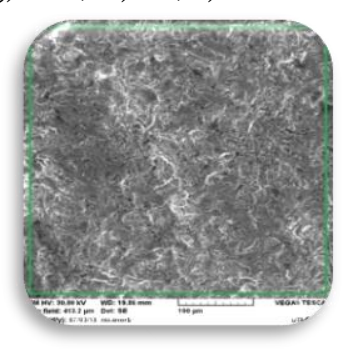

a.

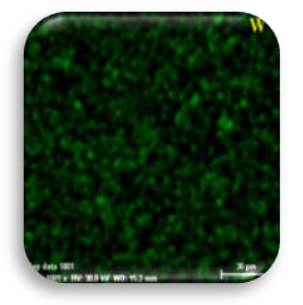

e.

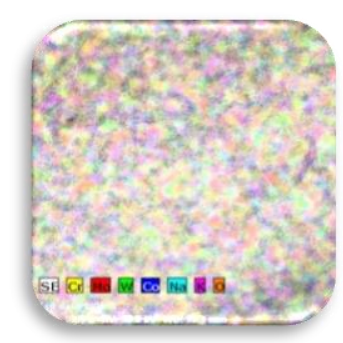

b.

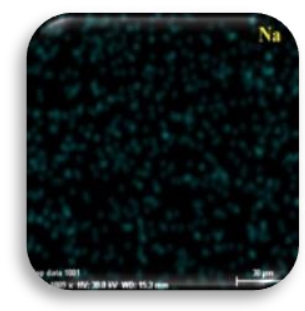

f.

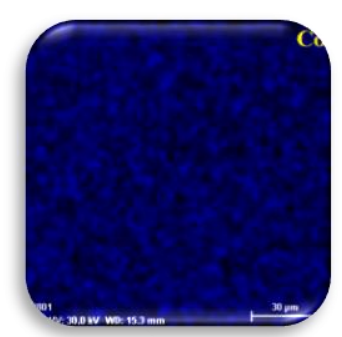

c.

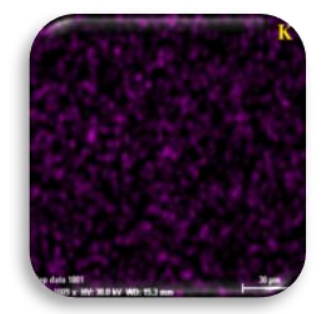

g.

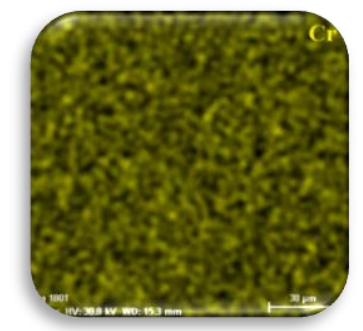

d.

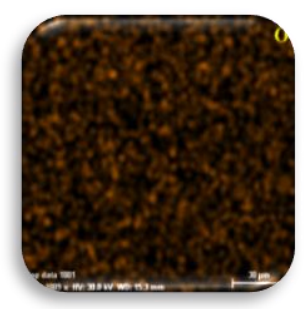

h.

Figure 3. Distribution of $\mathrm{Co}, \mathrm{Cr}, \mathrm{W}, \mathrm{Mo}, \mathrm{Na}, \mathrm{K}$ and $\mathrm{O}$ elements: a) surface under analysis, b) distribution of all elements on surface, c) Co, d) $\mathrm{Cr}, \mathrm{e}$ ) W, f) $\mathrm{Na}, \mathrm{g}$ ) $\mathrm{K}, \mathrm{h}$ ) $\mathrm{O}$

The analysis of the surfaces of experimental alloys after the electrochemical corrosion tests showed a generalized corrosion of the surface. The mechanical processing of the specimen surface influences, with low values, their resistance to electrochemical corrosion.

The chemical composition of the surface of $2 \mathrm{~S}$ specimen is given in Table 4. From the distribution of the main $\mathrm{Co}$ and $\mathrm{Cr}$ elements we may notice their stability in the environment of Fusayama-Meyer artificial saliva, with a slight degradation and formation of oxides characteristic to these elements having high resistance to corrosion. We may see the presence of sodium and potassium-based compounds on the surface (Figure 4). 
Table 4. Chemical composition of the surface of $2 \mathrm{~s}$ specimen after the test of resistance to electrochemical corrosion

\begin{tabular}{|c|c|c|c|c|c|c|}
\hline Element & $\mathbf{A N}$ & series & Net & [norm. wt.\%] & [norm. at.\%] & Error in \% \\
\hline Cobalt & 27 & $\mathrm{~K}$-series & 69527 & 51.34 & 41.71 & 1.33 \\
\hline Chrome & 24 & K-series & 49995 & 22.23 & 20.47 & 0.62 \\
\hline Tungsten & 74 & L-series & 6073 & 9.55 & 2.48 & 0.29 \\
\hline Oxygen & 8 & $\mathrm{~K}$-series & 4609 & 9.16 & 27.42 & 1.95 \\
\hline Molybdenum & 42 & K-series & 309 & 4.85 & 2.42 & 0.35 \\
\hline Sodium & 11 & K-series & 813 & 2.32 & 4.84 & 0.23 \\
\hline \multirow[t]{2}{*}{ Potassium } & 19 & K-series & 1204 & 0.51 & 0.63 & 0.04 \\
\hline & & & Sum: & 100 & 100 & \\
\hline
\end{tabular}

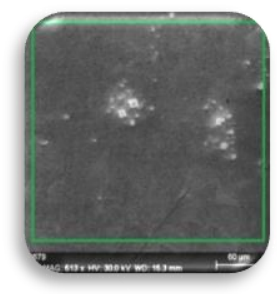

a.

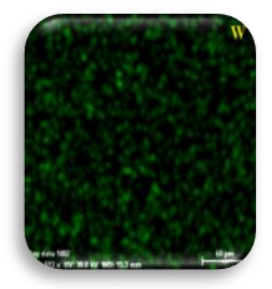

e.

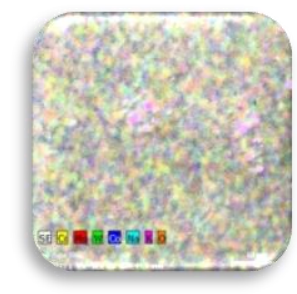

b.

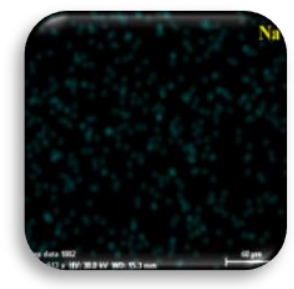

f.

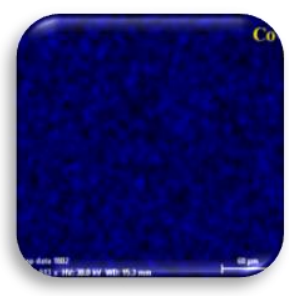

c.

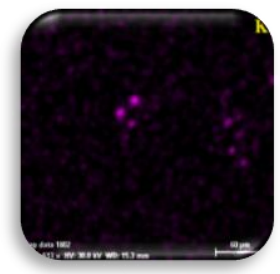

g.

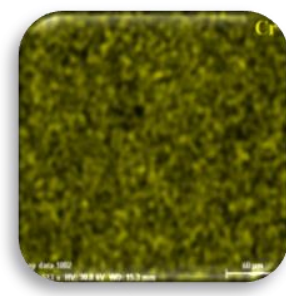

d.

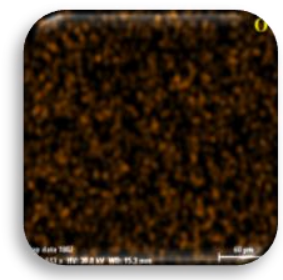

h.

Figure 4. Distribution of $\mathrm{Co}, \mathrm{Cr}, \mathrm{W}, \mathrm{Na}, \mathrm{K}$ and $\mathrm{O}$ elements on $2 \mathrm{~S}$ specimen: a) surface under analysis, b) distribution of all elements on the surface, c) Co, d) $\mathrm{Cr}$,

e) $\mathrm{W}, \mathrm{f}) \mathrm{Na}, \mathrm{g}) \mathrm{K}, \mathrm{h}) \mathrm{O}$

\section{Conclusions}

As it is well known, corrosion may affect the biocompatibility of dental alloys due to the humid environment, the contact with diverse types of ions, $p \mathrm{H}$ modifications, mechanical or electrochemical wear, all these factors leading to the release of metal ions, tissular inflammatory local reactions or systemic reactions (for example, allergic reactions).

In this context, we conducted a microstructural and chemical analysis of Co-Cr-W alloys used to obtain prosthetic restorations through additive manufacturing/SLM, after electrochemical corrosion in Fusayama-Meyer artificial saliva solution with $p \mathrm{H}=5.3$

The appearance of corrosion is generalized without any traces of pitting.

A subsequent analysis of the influence of rugosity of the surfaces of the specimens obtained from Co-Cr-W dental alloy processed by SLM might bring light on the effects of mechanical processing on corrosion in solutions with a different $p \mathrm{H}$.

\section{References}

1. HRYNIEWICZ, T., ROKICKI, R., ROKOSZ, K., Mater Lett, 62, no. 17-18, 2008, p. 3073

2. SAJI, V.S., CHOE, H.-C., Trans Nonferr Met Soc China, 19, no. 4, 2009, p. 785

3. FORNA, N.C., TATARCIUC, M., VITALARIU, A., BACIU, E.R., DIACONU-POPA, D., Romanian Journal of Oral Rehabilitation, 10, no. 4, 2018, p.13.

4. HANZL P., ZETEK M., BAKSA T., KROUPA T., Procedia Engineering, 100, 2015, p. 1405 
5. SAMES, W.J., LIST, F.A., PANNALA, S., DEHOFF, R.R., BABU, S.S., International Materials Reviews, 61, 2016, p. 315

6. BACIU, M.A., BACIU, E.R., BEJINARIU, C., TOMA, S.L., DANILA, A., BACIU, C., IOP Conference Series: Materials Science and Engineering, 374, 2018, doi:10.1088/1757-899X/374/1/012010

7. YADROITSEV, I., BERTRAND, P.H., SMUROV I., Appl Surf Sci, 253, no. 19, 2007, p. 8064

8. YVES-CHRISTIAN, H., JAN, W., WILHELMM, M.,KONRAD, W., REINHART, P., Phys Proc, 5, no. 2, 2010, p. 587

9. YAP, C.V., CHUA, C.K., DONG, Z.L., LIU, Z.H., ZHANG, D.Q., LOH, L.E., SING, S.L., Appl. Phys. Rev., 2, 2015, p. 1

10. GU, D.D., MEINERS, W., WISSENBACH, K., POPRAWE, R., Int. Mater. Rev., 57, 2012, p. 133

11. XIN, X.-Z., XIANG, N., CHEN, J., WEI, B., J Mater Sci, 47, no. 12, 2012, p. 4813

12. XIN, X.-Z., CHEN, J., XIANG, N., GONG, Y.,WEI, B., Dental Materials, 30, no. 3, 2014, p. 263.

13. VASLUIANU, R.I., FORNA, N.C., BACIU, E.R., ZALTARIOV, M.,VASILIU, L., MURARIU, A., Rev Chim., 69, (7), 2018, p.1714.

14. BOBU, L., MURARIU, A., TOPOR, G., BEZNEA, A., VASLUIANU, R., Comparative Evaluation of Casein Phosphopeptide - Amorphous Calcium Phosphate and Fluoride in Managing Early Caries Lesions. Rev. Chim., (70), no. 10, 2019, p. 3746.

15. BARlEAN, M.C., BAlCOS, C., BOBU, L.I,, CRETU, C.I., PlATON, A.L., STUPU, A., NICOLAICIUC, O., TOPOR, G., BEZNEA, A., POPESCU, E., Microbiological Evaluation of Surgical Site Infections in the Clinic of Oral and Maxillofacial Surgery of the Sf. Spiridon Clinical Hospital in Iasi, Romania. Rev. Chim., 70, (11), 2019, p. 4077.

16.VASLUIANU, R.I., UNGUREANU, D., JITARU, D., IOANID, A.D.,FORNA, N.C., Rev Romana Med Lab., 81, no. 2, 2010, p. 215.

17. EARAR, K., GRIGORE, C.A., BUDACU, C., TRINCA, L.C., MARECI, D., SINCAR, C.D., Electrochemical Behaviour of Titanium Based Biomaterials in Artificial Saliva. Rev. Chim., 68, (2), 2017, p. 396.

18. BUDACU, C.C., IOANID, N., ROMANEC, C., BALAN, M., PAVEL, L.L., PACURAR, M., ROSU, S., Dental Inclusion of Canine and Wisdom Tooth in Orthodontics Chemical Necroses. Rev. Chim., 69, (8), 2018, p. 2191.

19. FLORESCU, L., MATEI, M.C., RUGINA, A., MINDRU, D.E., ANTIGHIN, S.P., MASTALERU, A., TEMNEANU, O.R., Z-score: an indicator of protein-calorie malnutrition. Rev Med ChirSoc Med Nat Iasi, 121, no.3, 2017, p. 493.

$\overline{\text { Manuscript received: } 20.02 .2020}$ 